\title{
Kilka uwag o pisowni polskiej w Przewodniku do jezyka polskiego Michała Kusia (1646)
}

Słow a k luc z ow e: słownik; Michał Kuś; gramatyka; litery; głoska; grafia XVII wieku

Ke y w ord s: dictionary; Michał Kuś; grammar; letters; phone; 17th century orthography

\section{Wstęp}

Począwszy od XVI wieku na Śląsku i Pomorzu, obszarach etnicznie niejednorodnych, z najliczniej z obcych narodowości - wśród polskojęzycznych mieszkańców tych terenów - reprezentowanymi Niemcami, powstają pierwsze niemieckojęzyczne podręczniki polszczyzny. Pisane początkowo przez cudzoziemców w odpowiedzi na wyraźne zapotrzebowanie mieszkających w Polsce lub przyjeżdżających do Polski Niemców, służyły nauce języka polskiego jako obcego (por. Kępińska 2006: 43). W XVI i jeszcze w XVII wieku książki do nauki języka polskiego wyróżniała tendencja do scalania całego kursu języka w jeden podręcznik. W ramach tej tendencji wykształciły się trzy nurty: rozmówkowy (przewaga rozmówek), słownikowy (przewa- 
ga części leksykalnej) i gramatyczny (przewaga materiału gramatycznego). W drugiej połowie XVII wieku coraz bardziej widoczna jest już tendencja do specjalizacji działów i wydawania każdego z nich w ramach osobnych pozycji książkowych. Rozwój ten dotyczy również Dolnego Śląska, regionu, w którym zostały wydane cieszące się popularnością podręczniki polszczyzny (m.in. Macieja Dobrackiego ${ }^{1}$, Jerzego Schlaga ${ }^{2}$, Johanna Krumbholza ${ }^{3}$ ):

Do zmiany doszło po wojnie trzydziestoletniej, która zaważyła na całym życiu Śląska, budząc we Wrocławiu dążności praktyczne, związane z koniecznością odbudowy ekonomiki stolicy Śląska. Specjalizacja właśnie wynikała z praktycznego pędu poszukiwania dróg do udoskonalenia nauki języka polskiego. Wskutek tej specjalizacji wychodziły odrębne rozmówki, odrębna gramatyka itd. (Rombowski 1960: 122).

Przewodnik do Języká Polfkiego wpisuje się w nurt starszy, nurt podręczników scalających cały kurs, z dominacją jednego z działów nauki języka polskiego - w Przewodniku dominuje materiał słownikowy. Taki charakter Przewodnika nie dziwi, zważywszy na fakt, że jego autor zapisał się w historii metodyki nauczania języka polskiego jako zwolennik metody słownikowej. Kuś nie był odosobniony w swoich poglądach. Głównym reprezentantem leksykalnej (słownikowej) metody nauczania był w XVI wieku Murmelius, natomiast autor Przewodnika stał się jego kontynuatorem. Przewaga części słownikowej nad gramatyczną jest przyczyną, dla której w literaturze przedmiotu Przewodnik bywa różnie traktowany. Raz zaliczany jest do słowników, raz do gramatyk (por. Decyk-Zięba 2014).

\section{Autor i jego dzieło}

Dokładna data urodzenia Michała Kusia nie jest niestety znana, podobnie jak bliższe informacje o jego pochodzeniu i dzieciństwie. Wiadomo, że przyszedł na świat ok. 1600 roku we wsi Brzezimierz koło Oławy, miasteczka niedaleko Wrocławia, gdzie miejscowa ludność mówiła nie tylko po niemiecku, lecz również po polsku. Jego ojciec - Jerzy Kusche - był pastorem w Brze-

1 Goniec gramatyki polskiej (Oleśnica 1668), Gramatyka polska, niemieckim językiem wyrażona (Oleśnica 1669).

2 Neue gründliche und vollständige polnische Sprach-Lehre (Wrocław 1734).

3 Kurzgefaßte und deutliche deutsch-polnische Grammatik (Wrocław 1790). 
zimierzu. Jak widać, nazwisko autora i jego rodziny przyjmowało różne formy, poza wspomnianymi tu już wariantami Kuś i Kusche spotkać można także formy: Kusz i Kuschius. Inaczej niż jego ojciec, Jerzy Kusche, Michał nie używał zgermanizowanej formy nazwiska. Na kartach Przewodnika do języka polskiego podpisał się: Michael Kuschius. Pod takim imieniem i nazwiskiem autor występuje też w Bibliografii staropolskiej Estreichera (Estreicher 1905: 406). Zarówno Kusche, jak i zlatynizowany Kuschius to formy polskiego nazwiska Kuś (rzadziej: Kusz), w wieku XVII i wcześniej często spotykanego „tak na Śląsku, jak i w Prusiech” (Rombowski 1960: 243). W niniejszym artykule - tekście pisanym po polsku - stosowana będzie konsekwentnie polska forma nazwiska.

Brak niestety danych o początkach edukacji Kusia. Pewne jest tylko, że w 1620 roku zapisał się do Gimnazjum Toruńskiego, które cieszyło się wówczas doskonałą opinią. Tu mógł podszkolić swoją polszczyznę. W latach 1629-1631 studiował teologię na Uniwersytecie Wittenberskim. Jak widać, studia uniwersyteckie Kuś rozpoczął bardzo późno, czego przyczyną był brak pieniędzy. Dopiero stypendium, ufundowane przez Melchiora Thomasa i Matysa Liehra, umożliwiło mu studiowanie (Rombowski 1960: 243). Studiów jednak nie ukończył - stało się tak za sprawą Ernesta Pförtnera auf Pöpelwitz. Choć Kuś nie miał tytułu magistra teologii, Pförtner powołał go 8 grudnia 1631 roku na pastora w Sadkowie pod Wrocławiem, a cztery dni później „ordynował go na to stanowisko Ewangelicki Konsystorz we Wrocławiu” (Rombowski 1960: 244). Kiedy w 1638 roku zmarł Samuel Butschky, kaznodzieja polski i niemiecki w kościele św. Krzysztofa we Wrocławiu, na jego miejsce powołano właśnie Kusia. Równocześnie objął on kierownictwo Polskiej Szkoły św. Krzysztofa we Wrocławiu. Obydwa stanowiska piastował aż do śmierci. Zmarł 2 września 1654 roku.

Omawiany tu podręcznik jest jedynym dziełem Michała Kusia. Pełny jego tytuł brzmi: Wegweifer zur Polnifchen / vnd Deutfchen Sprache / Das ift: Eine gründliche / nothwendige anleitung / wie ein deutfcher Knabe / oder Mägdlein die Polnifche / hergegen ein Pohle auch die Deutfche Sprache leichter vnd eher / nicht allein recht fchreiben / ver/tehen / vnd reden lernen: Sondern auch auß einer Sprache in die andere verfetzen / vnd die Worte nachfchlagen könne. Przewodnik do Języká Polfkiego / To ieft: Gruntowna / potrzebna náuká iáko się Niemieckie Páchole y Dziewczątko Polfkiego / á záfz Polak Niemieckiego / Języká tatwiej y rychley / nietilko práwie pifáć / 
rozumieć / y mowić náuczyć / ná przefádzie / y fłow fzukáć może. Podręcznik został wydany we Wrocławiu, w 1646 roku, w oficynie wydawniczej Jerzego Baumanna młodszego. Najprawdopodobniej było to jedyne wydanie Przewodnika. Zygmunt Justus Ehrhardt, pastor w Baszynie, autor czterotomowej Prezbiterologii ewangelickiego Ślaska (Ehrhardt 1780-1789), twierdzi wprawdzie, że Przewodnik był wielokrotnie wznawiany, jednak jak dotąd nie odnaleziono żadnego innego wydania (por. Rombowski 1960: 244).

Przewodnik, co wynika z karty tytułowej, przeznaczony był przede wszystkim dla uczniów Szkoły Polskiej św. Krzysztofa we Wrocławiu: Der Polnischen Schulen zu Breßlaw / in Durck (!) gegeben (oddany do druku dla Polskiej Szkoły we Wrocławiu), ale - jak autor sam pisał w przedmowie - wśród użytkowników swojego podręcznika widział również chłopców i dziewczęta, którym język polski potrzebny jest w różnych sytuacjach życia codziennego, np. w handlu, pisaniu listów lub tłumaczeniu. Jak widać, przyświecały mu też cele pozaszkolne. Na karcie tytułowej widnieje zapis, że z Przewodnika Niemiec nauczy się łatwiej i szybciej pisać, rozumieć i mówić po polsku, a Polak po niemiecku. Informacja o przeznaczeniu podręcznika dla niemieckich i polskich użytkowników pojawia się tylko ten jeden raz. Ani w przedmowie (tekst niemieckojęzyczny), ani w słowach skierowanych do czytelnika (tekst polskojęzyczny) nie ma już mowy o Polakach jako potencjalnych odbiorcach. Język wyjściowy haseł w słowniku, język - skromnego wprawdzie - komentarza w części poświęconej polskiej gramatyce oraz fakt, że autor nigdzie nie komentuje gramatyki języka niemieckiego - wszystko to sugeruje zdecydowanie niemieckojęzycznego odbiorcę. Trudno więc oprzeć się wrażeniu, że podanie na stronie tytułowej jako adresatów dzieła i Niemców, i Polaków było po prostu chwytem reklamowym i zabiegiem merkantylnym. Miało powiększyć liczbę potencjalnych nabywców i ewentualne zyski ze sprzedaży (por. Budziak 2012: 97). Autor, głęboko przekonany, że istniejące na rynku wokabularze i podręczniki do nauki polskiego nie służą dobrze ani początkującym, ani zaawansowanym uczniom, wierzył, że oddaje użytkownikowi pożyteczną i przydatną książkę.

\section{Słów kilka o części słownikowej Przewodnika}

Część słownikowa Przewodnika - zajmująca 213 stron - to alfabetyczny słownik niemiecko-polsko-łaciński. Ukazanie się słownika o alfabetycznym 
układzie haseł było przełomowym momentem na gruncie leksykografii śląskiej i to właśnie Michał Kuś był inicjatorem i wykonawcą tego przedsięwzięcia (por. Sochacka 1972: 262). Słownik jest drukiem trzyszpaltowym i liczy 5664 hasła. Hasła niemieckie zajmują lewą szpaltę strony, polskie środkową, zaś prawą szpaltę wypełniają ekwiwalenty łacińskie, które - zdaniem autora - mają znającym łacinę pomóc w lepszym zrozumieniu wyrazów wieloznacznych. Łacina jest tu więc tylko narzędziem, a nie przedmiotem słownikowego opisu.

Zgodnie z zapowiedzią w przedmowie hasła niemieckie ułożone są w porządku alfabetycznym. Makrostruktura słownika ma bardzo prostą budowę. Wyrazy o tym samym rdzeniu nie są zebrane w tzw. gniazda wyrazowe, lecz są oddzielnymi hasłami w słowniku. Pokazuje to niniejsza ilustracja:

bieb Diebifach

Dieberey dicbptal Dicbract ftob多ity

ztoóficilen

gfoogienfitwo

fráosicuftiono

firécria fur

furax

furacitas

furtum

crumera

Hasła w słowniku są w większości jednowyrazowe. Sporadycznie zdarzają się związki wyrazowe (grupy nominalne i werbalne), niekiedy też kolokacje:

$\begin{array}{lll}\text { Haab vnd Gutt } & \text { Máiętność } & \text { Substantia } \\ \text { lincks vnd rechts } & \text { oboręcy } & \text { ambidexter } \\ \text { ftamm eines baums } & \text { pień / } \beta \text { czep } & \text { Jttrps (!) } \\ \text { biß wilkommen } & \text { wytáy } & \text { falve } \\ \text { zepfflein zum ftuelgang } & \text { czepek do czenionia ftolcow } & \text { balanus } \\ \text { zuflucht nehmen } & \text { ucziekác fie pod opiekę obronę } & \text { confugere }\end{array}$

Przy wielu hasłach autor podaje dwa, trzy, a czasem nawet cztery ekwiwalenty w języku polskim, np.: 


$\begin{array}{lll}\text { ander } & \text { inny / inßy / drugi } & \text { alius } \\ \text { auff } & \mathrm{w} / \text { ná / do / ku } & \text { in } \\ \text { dienftmagd } & \text { dziewká / fłużebnicá } & \text { ancilla } \\ \text { hengft } & \text { koń / ftádnik / drygat } & \text { caballus } \\ \text { letzte } & \text { pośledny / oftátny / oftáteczny } & \text { ultimus } \\ \text { rauch } & \text { chropowáty / kofmáty / oftry } & \text { afper } \\ \text { werffen } & \text { cifkác / ćiepác / rzucic } & \text { jacere }\end{array}$

Mikrostruktura słownika poza tym jest jednak bardzo uboga, pozbawiona przykładów użycia, kolokacji i frazeologii, autor rezygnuje także z podawania informacji gramatycznych czy stylistycznych.

\section{Kilka uwag o pisowni w Przewodniku}

Choć ukazujące się już od XV wieku gramatyki języka polskiego i języka niemieckiego zawierały część poświęconą ortografii, trudno dopatrzyć się w nich jasnych reguł i zasad pisowni zarówno w polszczyźnie, jak i w niemczyźnie. Piszący je gramatycy są miejscami jednomyślni, miejscami ścierają się ze sobą. Również siedemnastowieczne opracowania o charakterze ortograficzno-normatywnym nie zdołały ustalić jednolitego systemu graficzno-ortograficznego ani też zapobiec chwiejności i niekonsekwencji w pisowni. W obydwu językach upowszechniają się i utrwalają natomiast pewne tendencje graficzne i ortograficzne, mające swoich zwolenników i przeciwników.

Brak jasnych zasad pisowni w polszczyźnie dostrzegali cudzoziemcy, autorzy gramatyk i podręczników języka polskiego. Otwarcie pisze o tym Michał Kuś i, co więcej, na karb tej niedoskonałości kładzie ewentualne błędy w swoim dziele:

Trudno fie temu / ktory nowy druk wydawa / uftrzec wßytkich omyłkow / a zwłaßćza w Polfkim Języku / gdzie niemáß zadnych iftych reguł / według ktorychby fie pifác miáło / tak że fie y wtych K fiąfkách náydzie pomießánie liter / álbo iedná zá drugą poftánowiona / iáko to a zá a albo ą / c zá ć / 1 zá 1 / o zá ó / 〔 zá ś / rc. ale proßē baćznego y łafkáwego ćzytelniká / żeby tego niewiádomośći Autorá teto K fiąlki nieprzypi fował / ponieważ ten co litere fadzał / języká Polfkiego nierozumiáł. (De erratis. Ostatnia strona Przewodnika. Wyróżnienie: A.F. i A.J.) 
Trudno jednak wyrokować, który zapis można uznać za błąd, gdyż Kuś nie podaje w Przewodniku przyjętych reguł pisowni, a jego krytyczne wypowiedzi o innych gramatykach i podręcznikach języka polskiego nie pozwalają stwierdzić, których reguł mógł być zwolennikiem.

Poniżej przedstawiono najbardziej typowe i najciekawsze cechy pisowni stosowanej w Przewodniku. Podkreślić należy, że Kuś nie formułuje żadnych propozycji graficznych expressis verbis, przedstawione w artykule zwyczaje pisowniowe są więc wynikiem obserwacji stanu w Przewodniku, a nie wypowiedzi normatywnych autora.

\subsection{Zakres użycia wielkich liter}

Spośród zasad pisowni, przyjętych na potrzeby Przewodnika do języka polskiego Kusia, współczesnego czytelnika najbardziej zaskoczy ujednolicenie sposobu stosowania małych i wielkich liter w materiale polskim i niemieckim, a w szczególności - rezygnacja z zapisywania niemieckich rzeczowników wielką literą. Warto więc przypomnieć, że taka pisownia rzeczowników w niemczyźnie XVII wieku nie była jeszcze zasadą ${ }^{4}$ a raczej jedynie pewną manierą, obyczajem utartym wśród autorów i drukarzy. Obyczajem jednak silnie rozpowszechnionym, przeważającym w tekstach drukowanych (w rękopisach wielka litera stosowana była wyraźnie rzadziej), a w leksykografii polsko-niemieckiej i niemiecko-polskiej drugiej połowy XVII wieku stosowanym niemal bez wyjątków (por. Ernesti 1674, 1689, Malczowski 1688, Woyna 1690). Na tym tle Przewodnik Kusia ma więc prawo nieco dziwić. Leksykograf wielkimi literami zapisuje bowiem tylko wybrane hasła i ekwiwalenty, przy czym decydujące $\mathrm{w}$ ich doborze jest znaczenie wyrazu, a nie jego klasyfikacja morfologiczna.

Jak można się spodziewać, od dużej litery autor zaczyna (nieliczne w słowniku) nazwy własne, a także nazwy mieszkańców miast i państw, np.:

$\begin{array}{ll}\text { Rom } & \text { Rzym } \\ \text { Römer } & \text { Rzymiánin }\end{array}$

${ }^{4}$ Pisownia rzeczowników wielką literą została ostatecznie unormowana dopiero na początku XX wieku i obowiązuje do dzisiaj. Choć od czasów Gottscheda i Adelunga (połowa XVIII wieku) uchodziła za obowiązującą, nie była powszechnie akceptowana i konsekwentnie przestrzegana (por. Schneider 2015: 3). 


$\begin{array}{ll}\begin{array}{l}\text { Schlefien } \\ \text { Schlefier }\end{array} & \begin{array}{l}\text { Sląfko } \\ \text { Slężak }\end{array} \\ \text { Ungern } & \begin{array}{l}\text { Węgierfká źiemiá } \\ \text { Węgrzyn }\end{array} \\ \text { Weiffel } & \text { Wifłá }\end{array}$

Zgodnie z ówczesnym obyczajem w Przewodniku od wielkich liter rozpoczynają się hasła i ekwiwalenty związane z kościołem i wiarą - w czasach Kusia powszechne było wyrażanie szacunku poprzez wyróżnienie pierwszej, a niekiedy także drugiej (Der GOttesdien/t, GOtt der Sohn), a nawet wszystkich liter (DEr GOTT, przykłady pochodzą z Wokabularza Jana Malczowskiego, Malczowski 1688).

Poniżej wybrane przykłady haseł i ekwiwalentów z Przewodnika:

$\begin{array}{ll}\text { Capell } & \text { Káplica Kośćiołek } \\ \text { Kirche } & \text { Kośćioł } \\ \text { Predigen } & \text { Kázác } \\ \text { Predigt } & \text { Kázánie } \\ \text { Predigtftuel } & \text { Kázálnicá } \\ \text { Schöpffer } & \text { Stworzyciel }\end{array}$

Wielkimi literami Kuś systematycznie oznacza nazwy świąt (a), a także miesięcy i dni tygodnia (b), zapis nazw pór roku charakteryzuje już jednak wyraźna niekonsekwencja (por. (c)):

a)

$\begin{array}{ll}\text { Afchermittwoch } & \text { Popielec } \\ \text { Chriftag } & \text { Boże národzenie } \\ \text { Ofterfeft } & \text { Wielkanoc } \\ \text { Pfingffelt } & \text { Swiątki }\end{array}$

b)

$\begin{array}{ll}\text { Augftmonat } & \text { Sierpien } \\ \text { May } & \text { Máy } \\ \text { Weinmonat } & \text { Październik } \\ \text { Wintermonat } & \text { Liftopad }\end{array}$




$\begin{array}{ll}\text { Dinftag } & \text { Wtorek } \\ \text { Freytag } & \text { Piątek } \\ \text { Mittwoch } & \text { Srzodá } \\ \text { Sontag } & \text { Niedzielá }\end{array}$

c)

$\begin{array}{ll}\text { Herbft } & \text { Jeśien } \\ \text { lentz } & \text { wiofná } \\ \text { fommer } & \text { láto } \\ \text { winter } & \text { źimá }\end{array}$

Dużą literą zaczynają się w Przewodniku także niemieckie i, co zasługuje na podkreślenie, polskie rzeczowniki, będące określeniami osób - są to głównie zawody i funkcje, np. Koch/Kucharz, Befehlshaber/Porucżnik (por. a), ale również stopnie pokrewieństwa czy powinowactwa, jak $\mathrm{Ohm} /$ Wuy, Schwager/Szwágier (por. b). I tu dostrzec można pewne niekonsekwencje (por. c). Przykłady:

a)

Adel

Sláchcic

Bader

Láźiebnik

Buchdrucker

Drukarz

Fähndrich

Chorąży

Kauffdiener

Kupcżyk

Knecht

Sługá

Sattler

Siodłarz

Schufter

Swiec

Tromerer

Trębácż

Uhrmacher

Zegárnik

Wundarzt

Cyrulik

Ziegelftreicher

Cegielnik

b)

$\begin{array}{ll}\text { Eltern } & \text { Rodzice } \\ \text { Eydam } & \text { Zięc } \\ \text { Mütterlein } & \text { Mátuchná } \\ \text { Schweer } & \text { Swiekier } \\ \text { StieffSohn } & \text { Páśierb }\end{array}$




$\begin{array}{ll}\text { Tochter } & \text { Corá } \\ \text { Vater } & \text { Oćiec }\end{array}$

c)

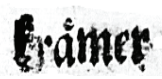
Arámauto
instition
mever
meverin
whtodars
stodánét
villicus
villica

Sposób, w jaki dystrybuowane są mała i duża litera, jasno wyłania się z następującego fragmentu Przewodnika:

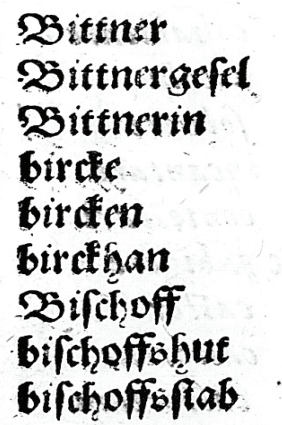

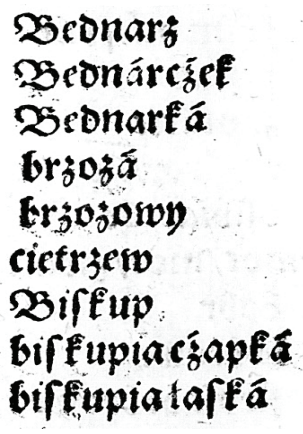

Sfonar:

Soconárç̧ef

Seonartá

Erojojowy

Birfup

biffuptacapfa

Giffupiatartá
Vietor

betula

betulaceus

attagen

Epifcopus

infula

litures

Jak widać, niemieckie rzeczowniki określające osoby, a więc Bittner/Bednarz, Bifchoff/Bifkup zaczynają się tu w obu językach od dużych liter, pozostałe hasła - nawet te, będące złożeniami określenia osoby i innego rzeczownika, na przykład bifchoffshut czy bifchoffsftab - konsekwentnie zapisywane są małymi literami.

Ostatnią grupą rzeczowników, które autor decyduje się zapisywać wielkimi literami, są nazwy zwierząt. Tu jednak trudno mówić o jakiejkolwiek konsekwencji - Kuś mniej więcej połowę spośród kilkudziesięciu lematyzowanych w Przewodniku niemieckich nazw zwierząt zapisuje wielkimi literami (por. a), co drugi spośród rzeczowników z tej grupy semantycznej notowany jest jednak małą literą (por. b, a także widoczne na powyższej ilustracji przy- 
kłady: birckhan/cietrzew). Podobnie dzieje się w wypadku polskich odpowiedników, Kuś bowiem dla obu języków stosuje te same zasady - w całym Przewodniku można znaleźć niewiele ponad dziesięć artykułów hasłowych, w których hasło zapisane jest dużą literą, a ekwiwalent małą lub (rzadziej) odwrotnie. Powyższe dotyczy także rzeczowników spoza grupy semantycznej omawianej w tym akapicie (por. c oraz hasło: tifchlein/Stolik na ilustracji poniżej). Przykłady:

a)

Kamelthier

Kaninchen

Kue

Quappe

Rabe

Widder

b)

bock

gan $\beta$

rehe

roß

falmen

c)

Buchbinder

Krüglein

Oftwind

Seele

totfchläger
Wielbłąd

Krolik

Krowá

Mieńtus

Kruk

Báran / Skop

koziel

gęś

śarná

koń

łoloś

kfięgarz

dźbanek

wiátr od wfchodu

dufchá

Mężoboycá

Trudno jest się dopatrzyć reguły, działającej w wypadku zapisów takich, jak przedstawione w punkcie (c), należy więc przyjąć, że są one wynikiem pomyłki autora (drukarza), a nie celowym zabiegiem. Raczej nie było celowe na przykład posłużenie się wielką literą przy zapisie polskiego rzeczownika Stolik, tym bardziej, że - podobnie jak większość wyrazów pospolitych - również inne nazwy artefaktów w Przewodniku zapisywane są małą literą (np. kołdrá, táźniá, piec i in.): 


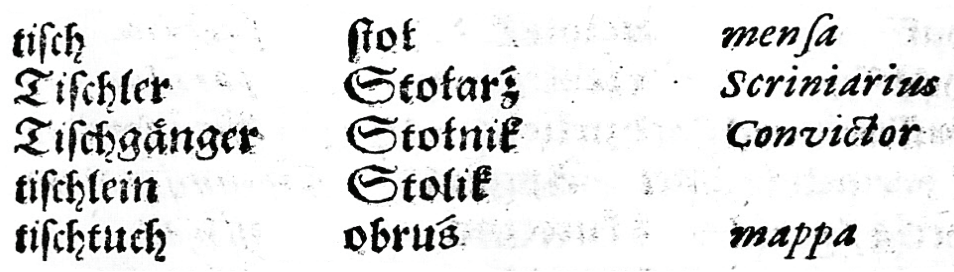

Warto wspomnieć, że inni leksykografowie, autorzy powstałych w 2. połowie XVII wieku słowników z językiem polskim i niemieckim, skłonni byli raczej stosować odwrotną zasadę: wzorem niemieckim zapisywali polskie rzeczowniki wielką literą. Taką tendencję wykazują na przykład słowniki Ernestiego - Forytarz (Ernesti 1674, por. a) i nieco późniejszy Hand-Büchlein (Ernesti 1689, por. b), a także, choć w mniejszym stopniu, Wokabularz Malczowskiego (Malczowski 1688, por. c). Na ich tle Przewodnik jest więc pracą wyjątkową.

Poniżej - dla porównania - podobizny fragmentów słowników Ernestiego i Malczowskiego.

a)

\section{Diem tam no 2 águiftu

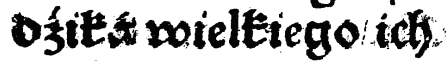 weíf Da in einem Mo. raft ein groß $\mathfrak{2} 8$ illo:}

b)

\section{Gielence in Seibe / Stan (Ob. rot $n$ Ciele; $\mathfrak{c b}$ if einges lender Shenfid) / obrotny Cztoniek.}

c)

\begin{tabular}{|c|c|}
\hline 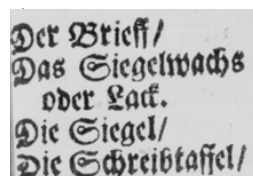 & 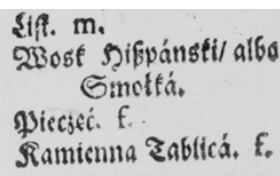 \\
\hline
\end{tabular}


Współczesne Przewodnikowi gramatyki języka polskiego, pisane przez cudzoziemców dla cudzoziemców, albo milczą na temat pisowni wielką literą, albo podają obowiązujące zdaniem ich autorów zasady i - co ważne - komentują sposób zapisywania rzeczowników w starszych lub współczesnych im drukach. Kwestię pisowni rzeczowników wielką literą poruszył m.in. Maciej Dobracki. W Gramatyce Polskiej (Dobracki 1669: 28-29) pisał:

Wreszcie trzeba tu poczynić konieczną uwagę o majuskułach, mianowicie, że wszystkie imiona własne (Propria Nomina), nazwy urzędów i stanowisk męskiego i żeńskiego rodzaju, sztuk i wszystkie te słowa, które coś szczególnego oznaczają, powinny i muszą od wielkiej litery być pisane, a więc: Bóg Gott, a nie bóg, Pan der Herr, a nie pan, Mąż der Mann, a nie mąż. Elżbietá Elisabeth, a nie elżbietá. Krolowa die Königin, a nie krolowa itd.

Zganić więc należy, że w różnych zarówno starszych jak i młodszych drukach, które ukazały się w Krakowie, Gdańsku i Toruniu, nie widać tej zasady, za to słowa te od małej litery są pisane; Można w nich znaleźć słowo Bóg od małego b, Ocieć od małego o, Przyjaciel od małego p napisane. Skoro nie jest to zgodne z poprawną ortografią, to trzeba zawczasu przestrzec przed tym nadużyciem młodzież i wszystkich, którzy się tu mylą. (tłumaczenie A.F. i A.J.)

W materiale polskim Przewodnika, zgodnie z ówczesnym zwyczajem 5 , pominięto wielkie litery z diakrytami. Tam, gdzie można by oczekiwać wielkiego $\dot{C}, \dot{S}, \dot{Z}, \dot{Z}$ czy $€$ (a nie jest tych przypadków wiele, jak już wspomniano polskie wyrazy - poza wymienionymi powyżej wyjątkami - zapisywane są w słowniku małymi literami), drukarz zastosował odpowiednik bez znaków diakrytycznych, na przykład: Láźiebnik, Slężak, Swiq̨tki, Zyd, Zywiot i in. Podobnie ma się rzecz z przegłosem w materiale niemieckim - umlauty pojawiają się wyłącznie nad małymi literami, w całym Przewodniku nie znajdzie się ani jednego hasła, zapisanego przez $\ddot{A}$, Ö czy Ü.

${ }^{5} \mathrm{~W}$ drukach z drugiej połowy XVII wieku, a nawet jeszcze w połowie wieku XVIII, wielkie litery z diakrytami stosowano bardzo rzadko. Gruszczyński zauważa na przykład brak znaków diakrytycznych w anonimowym Wörter-Büchlein z 1705 roku (por. Gruszczyński 2000: 36). Wielkich liter z diakrytami nie stosowali też Malczowski (1688), Ernesti (1674, 1689) Woyna (1690) ani Faber (1717). 


\subsection{Polskie samogłoski jasne i ścieśnione}

W połowie XVII wieku w piśmiennictwie polskim panował jeszcze zwyczaj oznaczania różnicy pomiędzy [a] jasnym, zapisywanym jako á (niekiedy również jako à) i [å] ścieśnionym, zapisywanym jako $a$. Samogłoski ścieśnione $\mathrm{z}$ polskiego systemu fonologicznego, a w konsekwencji także z druków, znikną bowiem dopiero w XVIII wieku. Można się więc spodziewać, że autor słownika z 1646 roku - aby pozostać w zgodzie ze stanem historycznym języka - będzie zapisywał jasne [a] jako á w takich miejscach, jak końcówki rzeczowników twardotematowych rodzaju żeńskiego czy przyrostki czasowników w formie bezokolicznika. I rzeczywiście: Kuś, zgodnie z oczekiwaniami, konsekwentnie stosuje się do tej zasady. Na stronach Przewodnika można więc łatwo znaleźć polskie ekwiwalenty rzeczownikowe z kreskowanym á, np.: drátwá, hámownicá, kápuftá, konewká, Kotká, Małżenká, Młynarká, mrowká, ochlodá, poźimká, rózgá, wiofná, wroná czy wyfpá. Kreskowane á pojawia się też w przyrostkach czasownika w bezokoliczniku - a tych w słowniku jest wiele, Kuś lematyzuje bowiem czasowniki w formie bezokolicznika, a nie, jak wielu mu współczesnych (por. np. Wokabularz Malczowskiego, Malczowski 1688 czy nieco młodszy Celaryus Fabera, Faber 1717), w pierwszej osobie liczby pojedynczej. Jako przykład opisanego działania mogą posłużyć ekwiwalenty: chwytác, deptác, obwiqzác, obmawiác, piecżętowác, pytłowác, viednác, zachowác i wiele innych.

Ścieśnione [å] w omawianym okresie powinno, zgodnie z zasadą, występować m.in. w rzeczownikowych sufiksach -arz i -an oraz w końcówkach przymiotników w rodzaju żeńskim. I tu znów trudno zarzucić Kusiowi brak konsekwencji czy niedostateczną staranność w dystrybucji liter: $a ́-a$. Oto kilka przykładów rzeczownikowych: Aptekarz, Bałwan, Cefarz, Gospodarz, Kucharz, krámarz, Murarz, Młynarz czy Száfarz. Konsekwencji Kusia dowodzą też ekwiwalenty: Fararz, Pleban czy Piernikarz, uwidocznione na poniższej ilustracji: 

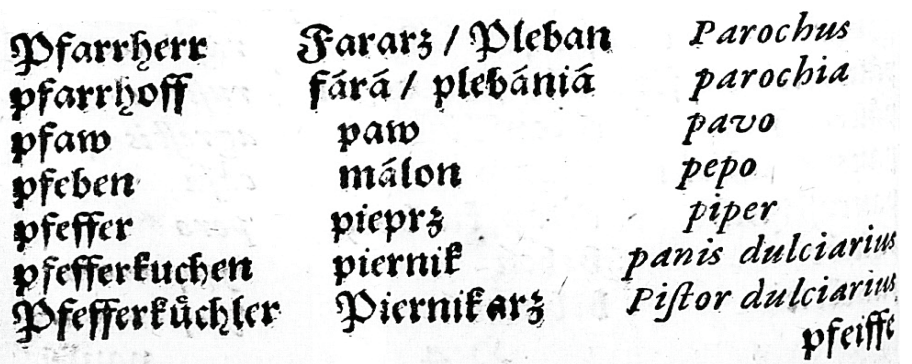

Nieco trudniej o przykłady przymiotnikowe, ich odnalezienie w Przewodniku nie jest jednak niemożliwe - choć ekwiwalentami niemieckich haseł przymiotnikowych w omawianym słowniku są formy mianownika liczby pojedynczej rodzaju męskiego, to w mikrostrukturze niektórych artykułów pojawiają się także przymiotniki żeńskie, spotkać je można zwłaszcza tam, gdzie hasło rzeczownikowe wymaga dwuwyrazowej ekwiwalencji. Na przykład: nocna robotá (ekwiwalent dla: nachtarbeit), máła mgłá (ekwiwalent dla: neblichen) czy ciafna ulicá (dla: enge gaffe). Jak widać, i tu Kuś starannie oznacza różnicę pomiędzy [a] jasnym i [å] ścieśnionym.

Staranność autora w dystrybucji znaków á i a szczególnie dobitnie odzwierciedlają te spośród artykułów hasłowych, które opisują wyrazy zbieżne w formie, a należące do różnych części mowy, por. na przykład zapis przymiotnika fwinia i rzeczownika /winiá:

\section{Fọering \\ fotinia wef \\ cicuta \\ féchein \\ fointá \\ fus}

W Przewodniku do języka polskiego, zgodnie z przeważającą w XVII wieku praktyką, różnica między ścieśnionym oraz jasnym $e$, a także między ścieśnionym oraz jasnym $o$, nie jest już oznaczona. Mówiąc precyzyjniej: Kuś nie stosuje znaków é i ó, a więc liter reprezentujących ścieśnione e i $o$. 


\subsection{Dystrybucja liter s if}

Autor Przewodnika zdaje się też wciąż przestrzegać zasady, w XVII wieku stosowanej już ze znacznie większą swobodą niż w wiekach wcześniejszych, mówiącej, iż litera $s$ zarezerwowana jest dla pozycji wygłosowych, natomiast $\int$ występuje we wszystkich innych pozycjach (również jako składnik dwuznaku $f z$ ). Kuś zapisuje zatem konsekwentnie: Miáftecżko, Puftetnik, fofná, fowá, ftolek, towárzyfz, uftapic. Zgodnie z oczekiwaniami wyrazy $\mathrm{z} s \mathrm{~W}$ wygłosie przedstawiane są natomiast w następujący sposób: cis, głos, kęs, mágnes, owies, pás.

Wyjątek na tym tle stanowi polski ekwiwalent námieftnik/Námiestnik słów niemieckich nachkömling oraz Verwalter. O ile w pierwszym wypadku zaskakuje mała litera na początku wyrazu, to w drugim niespodzianką jest znak $s$ w śródgłosie:

\section{nachęomling nämicfinite juccesfor Dermalter Rămicotnif Vicaries}

Przez $\int \mathrm{w}$ Przewodniku zapisywany jest konsekwentnie zaimek zwrotny fię. ${ }^{7} \mathrm{~W}$ innych natomiast wyrazach z palatalnym $s$, stojącym przed zmiękczającym je $i$ (zgłoskotwórczym bądź nie), głoska [ś] opatrywana jest dodatkowo znakami diakrytycznymi - Kuś oznacza zatem jej miękkość za pomocą grafemu ś. Widać to na przykład w ekwiwalentach: Kśiqże, ieśion, ośieł, przyśięgá, śikorá, śiodło, śitowie czy wyśiqkác. Zdarzają się jednak odstępstwa od tej reguły - autor zapisuje na przykład: fafiedztwo (choć Jeśień) i fierp (choć śiec), na kartach Przewodnika użytkownik znajdzie również liczebnik fiedm, czasownik fiedziec czy rzeczownik fiedzenie, por.:

${ }^{6}$ Gruszczyński (2000: 127) zauważa na przykład, że w badanych przez niego wokabularzach ryskich pozostały już tylko nieliczne ślady tej zasady.

7 Taki sposób zapisywania zaimka zwrotnego się postuluje również Maciej Dobracki (1669: 28-29). Powołuje się przy tym na takie autorytety jak Jan Kochanowski i Andrzej Maksymilian Fredro, którzy się zapisywali bez kreseczki nad $s$. 


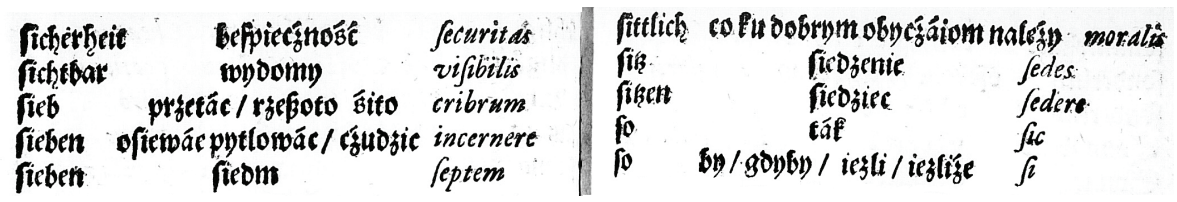

Niekonsekwencję w dystrybuowaniu liter, oznaczających stojące przed $i$ palatalne $s$, dobitnie pokazuje też poniższa ilustracja:

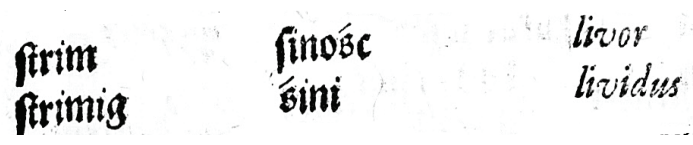

We wszystkich innych pozycjach - w wygłosie oraz przed spółgłoską w nagłosie i w śródgłosie - miękkość palatalnego $s$ symbolizowana jest kreskowaniem. Kuś systematycznie zapisuje tę głoskę jako $s$ w wyrazach Kościół, radość, śćiáná, ścigáć, wielkość, zazdrość, a także w wygłosowych: gęś, łofoś, łoś czy Wieś.

W tym miejscu warto też zwrócić uwagę na znamienne dla Przewodnika podwójne oznaczanie miękkości spółgłosek - Kuś konsekwentnie kreskuje spółgłoski palatalne, stojące przed zmiękczającą je samogłoską $i$, por. np.: ćiećiorká, ćieply, ćiotká, ćifawy, Grudźień, oćiec, źiemiá czy przytaczane już wcześniej: Jeśień, przyśięgá, śikorá. Nie jest w tym zresztą odosobniony, jako przykład współczesnej Kusiowi publikacji o podobnej cesze niech posłuży choćby Forytarz Jana Ernestiego (Ernesti 1674), w którym czytelnik znajdzie analogiczne zapisy: ćiepło, Grudźień, Pośiłek, śiáno etc. Ale znajdą się również głosy przeciwne tej praktyce, choćby głos Dobrackiego (1669: 25-26):

Uważa się za niepotrzebne znaczenie kreseczką miękkich liter ${ }^{8}$ ć ń ś i ź, jeśli stoją po nich dwie samogłoski, a więc w następujących wyrazach: ćiáło, der Leib, ćiáfno, gedrenge, ńiebo, der Himmel, śiodło, der Sattel, źiemiá, die Erde i inne. Gdyż tych słów nawet bez kreseczki nie da się raczej inaczej wypowie-

${ }^{8}$ Dobracki nie odróżniał głoski od litery. 
dzieć. Tego samego zdania jest uczony jezuita Grzegorz Knapski w Proœm.

Thefaur. Tom. I. (tłumaczenie A.F. i A.J.)

Charakterystyczne dla Przewodnika jest także niekreskowanie wygłosowego [ć] w bezokolicznikach ekwiwalentów czasownikowych (a także w kilku innych wyrazach, np. Zięc), co pokazuje poniższa ilustracja. Niekreskowane autor pozostawia niekiedy także wygłosowe [ń], ta reguła nie jest jednak ściśle przestrzegana. I tak w słowniku występują zarówno rzeczowniki: Kwiećien, Grudźien, Sierpien czy Jeśien, jak i: Stycżeń, Wrżeśień czy koń.

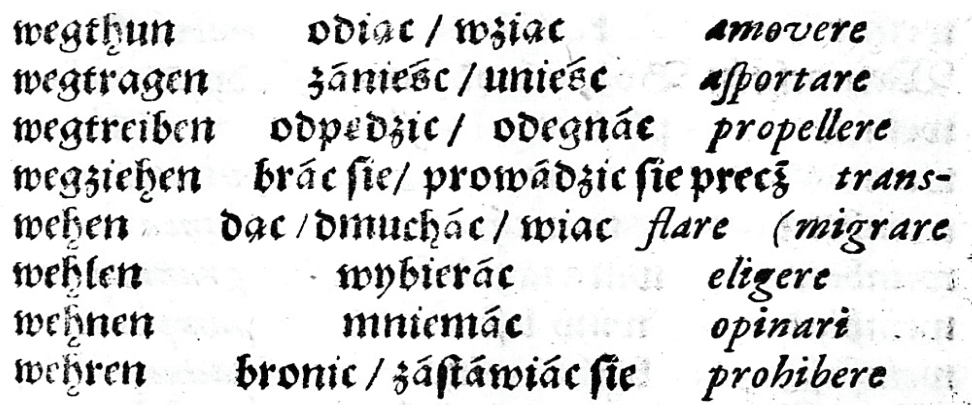

\subsection{Niezgłoskotwórcze [i]}

Sposób, w jaki w Przewodniku oznaczane jest niezgłoskotwórcze [i] (w dzisiejszej polszczyźnie realizowane jako $j$ ), charakteryzuje pewien brak konsekwencji. W nagłosie głoska [i] zapisywana jest - jak się może wydać po pobieżnym przejrzeniu słownika - jako $i$, np.: iábłecnik, iáchác, iáie, iárziná, iárzębiná, iástrząb, iednák, iednorożec, ież, ięzyk i wiele innych. Ale bardziej uważna lektura Przewodnika pozwoli odkryć ekwiwalenty zapisane w następujący sposób: jármark, jarzmo, jutro, jutrzeyfzy, jutrzenká. Taką właśnie pisownię postuluje m.in. cytowany już tu Maciej Dobracki. W swojej Gramatyce polskiej Dobracki piętnuje pisownię $i$ w nagłosie. Niewłaściwy jego zdaniem jest zapis: iáfność, iámá, iáłmużná etc. - według Dobrackiego (1669: 14) we wszystkich tych wyrazach zamiast $i$ w nagłosie powinna stać jota.

W śródgłosie głosce [i] odpowiadają - w zależności od kontekstu - litery $i$ lub $y$, a wyjątkowo także $j$. W pozycji między dwiema samogłoskami nie- 
zgłoskotwórcze [i] zapisywane jest jako i, np.: boiaźń, dwoiáko, iáie, páięcżená, przyiaciel, rękoieść, fzyiá, troie, záiqc. Wyjątek stanowi tu głoska [i], następująca bezpośrednio po literze $i-\mathrm{w}$ takim wypadku [i] przedstawiane jest jako j, np.: pijawká, żmijá. Z kolei do oznaczania dźwięku [i], występującego po samogłosce, ale przed spółgłoską, Kuś stosuje grafem $i$, por.: náidek, ftáiniá, zeiśc fię lub y, por.: Mężoboycá, podeyrzliwy, woyná. W pozycji wygłosowej, po samogłoskach innych niż [y], autor systematycznie zapisuje głoskę [i] za pomocą litery y, por. np. ekwiwalenty: gnoy, inácżey, Máy, nigdziey, obycżáy, Ráy, rodzáy, woyfko, Wuy czy złodźiey. Jak można się spodziewać, w derywatach, utworzonych poprzez dodanie do wyrazów z wygłosowym $y$ przyrostka rozpoczynającego się spółgłoską, stosowana jest już litera $i$. Ilustrują to następujące przykłady:

bieb

Diebifch stoogity

Stod

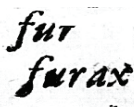

\section{Dicbercy}

W pozycji wygłosowej, ale po samogłosce [y], Kuś przedstawia niezgłoskotwórcze [i] za pomocą znaku i, por. Stryi:

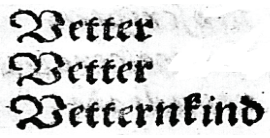

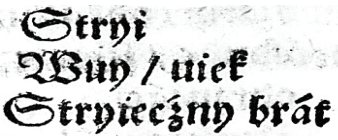

patruus

Avunculus

Patruelis

\subsection{Litera $x$}

W XVII wieku ważą się losy litery $x$, przejętej wraz z alfabetem łacińskim. Zalecenia gramatyków zmierzają w kierunku rezygnacji z $x$ na korzyść ks. Jeremiasz Roter, autor Klucza do polskiego i niemieckiego języka (Roter 1616) wprawdzie umieszcza $x$ w zestawieniu liter polskiego alfabetu, opisuje też wymowę tej głoski i podaje przykłady (Xiadz, xiqżę, xięgá), ale jednocześnie stwierdza, że „uczeni Polacy powyższe słowa raczej wyłącznie przez $K s ́$ piszą". Jeszcze bardziej zdecydowane stanowisko wobec litery x zajmuje Dobracki (1669) - nie dość, że nie podaje $x$ w zestawieniu liter polskiego alfabetu, to jeszcze przekonuje, że ,za $x$ Polacy piszą kś”. Przewodnik do języ- 
ka polskiego potwierdza jego słowa, u Kusia bowiem przeważa już pisownia przez $k s$ :

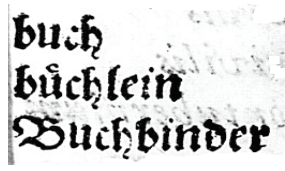

Jiurft gricher

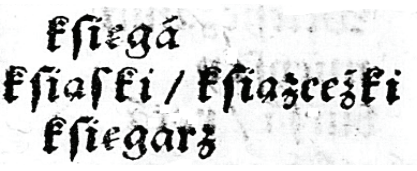

Rgiáge

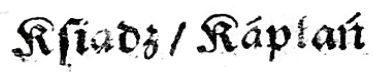

liber

libelles

libraritus

Princeps

sacerdos

Zdarza się jednak dawny zapis jako $x$ :

\section{STono Xiése/ Miefiac Luna}

\subsection{Zapożyczenia $\mathrm{z}$ laciny i greki}

Gramatycy XVII wieku postulowali, by rzeczowniki zapożyczone z łaciny i greki zapisywać literami polskiego alfabetu:

I to na koniec koniecznie trzeba zauważyć, że te polskie imiona (rzeczowniki), które swój początek mają w łacińskich i greckich słowach, wyłącznie polskimi literami pisane być muszą. Nie piszę więc Canclerz, tylko Kanclerz ein Kantzler, Secretarz, tylko Sekretarz ein Secretarius, Philofoph, tylko Filozof ein Philofophus. Piszę zatem Kryftus, a nie Chrystus, Krześciáńin, a nie Chrześćiánin ein Chrift, Jftoryk, a nie Hiftoryk ein Hiftoricus lub Gefchichtfchreiber, Afekt, a nie Affect eine Affection. Jak również Konftytucya, a nie Conftitutia die Satzung, Suplikácya lub Supliká, a nie Supplicátia, Koronácya, a nie Coronátia die Crönung itd. Tego zdania jest też słynny jezuita Knapski w swoim PolonoLatino-Græco Diction. (Dobracki 1669: 5; tłumaczenie A.F. i A.J.)

Choć Kuś wyraźnie stroni od notowania ekwiwalentów polskich obcego pochodzenia, to jednak w jego Przewodniku można zauważyć nieśmiałe próby realizacji powyższego postulatu, por.: 


\section{Canklet Ráncters Cancellarius \\ Carbinal Rároynat Cardinalis}

Poniżej przykład rzeczownika zapożyczonego, zapisanego jednak wbrew postulowanej zasadzie:

\section{Efgrift Cogrescianin Christianus}

\section{Podsumowanie}

Zasady pisowni, które przyjął Kuś, są typowe dla polszczyzny połowy XVII wieku, obrazują, zwłaszcza w zestawieniu z poglądami i postulatami współczesnych Kusiowi gramatyków, charakterystyczne dla XVII wieku ścierające się i konkurujące ze sobą tendencje graficzne i ortograficzne. Wprawdzie wszystkie miały na celu ustalenie jednolitego systemu graficzno-ortograficznego, ale różnorodność proponowanych rozwiązań zdecydowanie utrudniała jego osiągnięcie. Ilustracją takich (oryginalnych) rozwiązań, których notabene brak w Przewodniku, jest m.in. postulat Dobrackiego (1669: 28), by w niektórych rzeczownikach, a także czasownikach, w szczególności tych złożonych, koniecznie rozdzielać kreską te spośród sąsiadujących ze sobą liter, które przez mniej doświadczonego czytelnika mogłyby zostać uznane za dwuznaki (np. $d z$ czy $r z$ ). W konsekwencji doprowadziłoby to bowiem nie tylko do niewłaściwego odczytania wyrazu, ale także do błędnej interpretacji znaczenia, np. od-ziewam vs. odziewam, mier-że się vs. mierzę się. Jak wspomniano, Kuś nie jest zwolennikiem takiego zapisu, por.:

\section{meffen \\ verorieffen}

miersic

imiersec metiri

pigere 


\section{Słowniki i gramatyki}

Dobracki M., 1669, Polnifche Teutfch erklärte Sprachkunft. Darinn die überauß Wortreiche, Hochzierliche, vollkommene Helden-Sprache der Pohlen, auß ihren Gründen erhoben, dero Eigenfchafften und Kunftttücke völliglich entdecket, und in eine richtige Form der Kunft zum erften mahle gebracht worden. Grámátyká Polska, Niemieckim językiem wyrażona, Oleśnica.

ERnesti J., 1674, Forytarz Języka Polskiego, Osobne Rzeczy niemal wszystkich stowa mowy rożne y Rozmowy dwie w sobie zawierajacy, Niebiegłem w Języku tem, a osobliwie Młodźi wrocławskiej ku lepszemu wystawiony. Förderer der Polnischen Sprache [...] von [...] der Polnischen Schul daselbst Moderatore Breszlau [...],Wrocław: In der Baumannischen Erben Druckerey druckis Gottfried Gründer.

Ernesti J., 1689, Polnisches Hand-Büchlein Darinnen Nebst denen Stamm-Vieldeutenden-Sprüch-Wörtern, auch allerhand täglich vorfallende Redens-Arten enthalten. Vor die Breßlauische Polnische Schul verfertigt, Świdnica: Drukarnia Christiana Olsena.

Faber A., 1717, Celaryus polski, Oder Nach der Methode Des Lateinischen Libri Memorialis Cellarii, Vortheilhafftig eingerichtetes Polnisch-und Deutsches Wörter-Buch, Brzeg.

Malczowski S. J., ${ }^{2} 1688$, Der Jugend zu Nutz Deutsch und Polnisches vermehrtes und verbessertes Vocabularium. To iest, Bardzo potrzebny dla Młodzi Niemiecki y Polski Wokabularz, Riga: G.M. Nöller.

Roter J., 1616, Schlüffel zur Polnifchen vnd Teutfchen Sprach. Das ift: Recht gründliche Anleitung / wie nicht allein ein Teutfcher die Polnifche / sondern auch / wie ein Pole die Teutfche Sprach / leichter vnd eher lefen / verftehen / reden / vnd fchreiben lernen könne. Klucz do Polfkiego y Niemieckiego Jezyká. To jeft: Gruntowna náuká / Jáko śie nie tylko Niemiec Polfkiego : Ale jáko śie y Polak Niemieckiego jezyká / látwiey y rychley czytáć / zrozumieć / mowić y pifáć náuczyć może, Wrocław.

Woyna J. K., 1690, Kleiner Lust-Garten, Worinn Gerade Gänge Zur Polnischen Sprache angewiesen werden, Gdańsk: Thomas Johann Schreibers Verlag und Schriften.

\section{Bibliografia}

BudziaK R., 2012, Zur ältesten Geschichte der deutsch-polnischen Lexikographie. Wörterbücher aus dem 16. und 17. Jahrhundert, Zeitschrift für Slavistik, LVII/2012, s. 93-105.

Dесүк-ZiЕ̨вA W., 2014, Z historii gramatyk języka polskiego, [on-line:], http://www. gramatyki.uw.edu.pl/about/history, [15.12.2014]. 
Ehrhardt S. J., 1780-1793, Presbyterologie des Evangelischen Schlesiens, Legnica: Johann Gottfried Pappäsche.

FrąCZEK A., 2010, Słowniki polsko-niemieckie i niemiecko-polskie z przełomu XVII i XVIII wieku. Analiza leksykograficzna, Warszawa: Wydawnictwo Uniwersytetu Warszawskiego.

GRUSZCZYŃSKI W., 2000, Wokabularze ryskie na tle XVI- i XVII-wiecznej leksykografii polskiej, Warszawa: Oficyna Wydawnicza ASPRA.

Just A., 2014, Michael Kuschius, Wegweifer zur Polnifchen / vnd Deutfchen Sprache [...], [on-line:], http://www.gramatyki.uw.edu.pl/, [15.12.2014].

Just A., 2015, Przewodnik do języka polskiego Michała Kusia-pierwszy niemiecko-polski słownik alfabetyczny na Ślasku, Poradnik Językowy, z. 1, s. 128-135.

KĘPIŃSKA A., 2006, Dawne gramatyki języka polskiego, Biuletyn Informacyjny Biblioteki Narodowej 4/179/2006, s. 43-48.

Rombowski A., 1960, Nauka języka polskiego we Wrocławiu. (Koniec wieku XVI połowa wieku XVIII), Wrocław: Zakład Narodowy im. Ossolińskich.

SchneIDER M., 2015, Geschichte der deutschen Orthographie unter besonderer Berücksichtigung der Entwicklung seit 1994. Materialien zur (neuen) deutschen Orthographie, Universität Marburg, s. 1-30, [on-line:], http://decemsys.de/sonstig/ gesch-rs.pdf

Sochacka S., 1972, Gramatyki i słowniki polskie na Śląsku w XVII-XVIII wieku. (Stan badań i postulaty badawcze), Studia Ślaskie. Seria nowa, t. XXI, s. 245-265.

\section{Some Remarks on the Polish Spelling in Przewodnik do Jezyka Polskiego by Michał Kuś (1646) \\ ( summary)}

The subject of this article is the Przewodnik do Języká Polfkiego [Guide to the Polish Language] by Michał Kuś published in 1646. This guide is made up of two parts - an extensive dictionary and a grammar - a course book for learning Polish that is more than a dozen pages long.

The article's introduction brings to light the silhouette of the author of Przewod$n i k$ and describes the structure of his work. In further paragraphs the authors focus on issues concerning the seventeenth-century Polish spelling. The article presents the most typical and interesting features of spelling used in the guide, contrasts them with the views and recommendations of grammarians contemporary to Kuś, and compares the features with the spelling characteristics of the authors of several other seventeenth-century Polish-German and German-Polish dictionaries. 
